\title{
Phospholipid signaling pathway in Capsicum chinense suspension cells as a key response to consortium infection
}

María E. Sánchez-Sandoval1 ${ }^{1 \dagger}$, Graciela E. Racagni Di-Palma², Victor M. González-Mendoza ${ }^{3 \dagger}$, Yahaira A. Cab-Guillén ${ }^{1}$, José A. Muñoz-Sanchez ${ }^{1}$, Ana Ramos-Díaz ${ }^{4}$ and S. M. Teresa Hernández-Sotomayor ${ }^{1 *}$ (D)

\begin{abstract}
Background: Mexico is considered the diversification center for chili species, but these crops are susceptible to infection by pathogens such as Colletotrichum spp., which causes anthracnose disease and postharvest decay in general. Studies have been carried out with isolated strains of Colletotrichum in Capsicum plants; however, under growing conditions, microorganisms generally interact with others, resulting in an increase or decrease of their ability to infect the roots of $C$. chinense seedlings and thus, cause disease.

Results: Morphological changes were evident $24 \mathrm{~h}$ after inoculation (hai) with the microbial consortium, which consisted primarily of C. ignotum. High levels of diacylglycerol pyrophosphate (DGPP) and phosphatidic acid (PA) were found around 6 hai. These metabolic changes could be correlated with high transcription levels of diacylglycerol-kinase (CchDGK1 and CchDG31) at 3,6 and 12 hai and also to pathogen gene markers, such as CChPR1 and CchPR5.

Conclusions: Our data constitute the first evidence for the phospholipids signalling events, specifically DGPP and PA participation in the phospholipase C/DGK (PI-PLC/DGK) pathway, in the response of Capsicum to the consortium, offering new insights on chilis' defense responses to damping-off diseases.
\end{abstract}

Keywords: C. chinense, Colletotrichum species, Phosphatidic acid, Plant-pathogen, Biochemical response, Phospholipase

\section{Background}

Chili was domesticated in Mexico, where 4 of the 5 species of Capsicum are cultivated, including $C$. frutescens, $C$. annuum, C. pubescens and C. chinense. However, C. chinense is the only species of chili thought to have originated in Mexico, given its uses, including traditional uses, among settlers from the Yucatan region. Under field conditions, these crops are susceptible to pathogen infections,

\footnotetext{
* Correspondence: ths@cicy.mx

†María E. Sánchez-Sandoval and Victor M. González-Mendoza contributed equally to this work

${ }^{1}$ Unidad de Bioquímica y Biología Molecular de Plantas, Centro de Investigación Científica de Yucatán, Mérida, Yucatán, Mexico

Full list of author information is available at the end of the article
}

among which special attention has been paid to Colletotrichum spp.

The Colletotrichum genus has been related to anthracnose disease and postharvest decay in a wide range of tropical, subtropical and temperate fruits, crops and ornamental plants [1-4].

Species, such as C. acutatum, C. boninense, C. brevisporum, C. cairnsense, C. capsica, C. cliviae, C. coccodes, C. dematium, C. fructicola, C. queenslandicum, C. scovillei, C. siamense, C. simmondsii, C. truncatum, and C. gloeosporioides have been detected in Capsicum spp. plants with anthracnose symptoms [5-7]. 
The mechanism of Colletotrichum infection and the defense mechanism of Capsicum have been reported from studies carried out with isolated Colletotrichum strains $[8,9]$.

During plant-pathogen interactions, a precise signaling process is indispensable for the successful adaptation and survival of the plant. There are many studies on host plant defense systems and pathogenic invasion effectors along with their hormone related pathways, such as salicylic acid (SA) and/or jasmonic acid (JA) [10-15]. However, there have been only a few studies related to the phospholipid signal transduction pathways associated with the response to pathogens, particularly the pathways that involve phospholipid-derived molecules as second messengers, or hypersensitive response (HR) [16, 17]. Phosphatidic acid is a very important signaling molecule that can modulate the activities of kinases, phosphatases, phospholipases and other proteins involved in membrane trafficking, calcium signaling and biotic and abiotic stress responses [18-20].

In a previous study, we evaluated the effect of SA and methyl jasmonate (MJ) on phospholipid signaling in $C$. chinense Jacq. cell suspension cultures. Treatment with SA inhibited phospholipase C (PLC) and phospholipase $\mathrm{D}$ (PLD) activities, while treatment with $\mathrm{MJ}$ increased both phospholipases activities [20]. Regarding the hypersensitive response, the PA content was related to the onset of HR and phospholipidic signalling in an overactivation of defensive response lines (Disease Suppression 1, DS1, from tobacco plants), which were challenged with Ralstonia solanacearum [17, 21]. Transient accumulation of both PA and diacylglycerol pyrophosphate (DGPP) studies were conducted in tomato suspension cells [22, 23]. Cells treated with a pathogenic elicitor showed high levels of PA, which was subsequently metabolized to DGPP [22]. When DGPP and PA were added, the induction of the expression of elicitorresponsive genes was observed in the absence of the elicitor [23].

The roots of plants establish a relationship with the microorganisms present in the rhizosphere. These interactions can involve either beneficial or pathogenic microorganisms [24, 25]. Both types of interactions trigger a complex response that determine the success of pathogenic proliferation and development in the plant. In recent years, the response of plant cells to pathogenic microorganisms has been studied mainly using single pathogen species [26-29]. However, the cellular response is even more complex under field conditions, since microorganisms tend to form consortia with compatible microbes [30]. These microbes may have an inhibitory or synergistic effect on the onset and development of an infection. Here, we propose to study the cellular and biochemical responses to the microbial consortium isolated from rotting roots and fruits in $C$. chinense plants.

In the present work, a $C$. chinense suspension cell system was used to study the role of the phospholipid signalling pathway in response to a consortium infection. We sought to first correlate the generation of important phospholipid-derived molecules with the expression of the associated genes in response to the microbial consortium from C. chinense plants in order to understand the phospholipid signal transduction that occurs during the interaction between $C$. chinense suspension cells and a microbial consortium, primarily consisting of C. ignotum (93.6\%).

\section{Materials}

Radiolabeled $\left[{ }^{32} \mathrm{P}\right] \gamma$-ATP was obtained from Amersham Pharmacia Biotech (UK). The bicinchoninic acid (BCA) protein assay reagent was purchased from Pierce Chemical Co., Ltd., and other chemicals were provided by Sigma Aldrich. Murashige and Skoog (MS) medium were supplied by Phytotechnologies Inc. The commercial ZimoBiomics DNA kit was purchased from Zimo Research. Chloroform, methanol, pyridine, and formic acid were purchased from J.T. Baker Co. TLC plates were supplied by Merck .

\section{Biological material}

Capsicum chinense cell suspensions were obtained via the disaggregation of calli and cultivation in MS [31] at $\mathrm{pH}$ 5.6. This medium was supplemented with $0.5 \mathrm{mM}$ myo-inositol, $0.02 \mathrm{mM}$ thiamine, $0.2 \mathrm{mM}$ cysteine, $4 \mu \mathrm{M}$ 2,4-dichlorophenoxyacetic acid and 3\% sucrose according to a previous report [20]. The cells were subcultured every 14 days as previously reported [20] and grown with shaking (100 rpm) under continuous light at $25^{\circ} \mathrm{C}$.

The consortium, was obtained from the rhizosphere of C. chinense plants with symptoms of wilt from Yucatán, México. For growing the microbial consortium, the method used, was described by Dhingra and Burton [32]. The consortium (mycelium) was maintained at $25{ }^{\circ} \mathrm{C}$ in the dark on modified agar media (2\% Bacto agar, 10\% vegetable juice (Herdez V8 juice, containing 8 vegetables, carrot, tomato, beetroot, spinach, kale/leaf cabbage, celery, parsley and lemon juice) to get reproductive structures [33, 34]. The microbial consortium was cultivated in Petri dishes; the material was flooded with water and scrapped using the end of a sterile glass slide. The resulting suspension was filtered through $50 \mu \mathrm{m}$ Miracloth, as described by Sharma et al. (2015) [35] and incubated at $37^{\circ} \mathrm{C}$ for $3 \mathrm{~h}$, as suggested in Shipton (1985) [36].

Then, it was maintained at $4{ }^{\circ} \mathrm{C}$, and filtered again prior to use [37]. The filtrate was referred to as a conidial suspension (cs, cells/mL). In order to standardize the 
amount of inoculum employed in the infection experiments, the number of $C$. ignotum conidia was quantified. All cs used were attenuated by heating at $95^{\circ} \mathrm{C}$ for $10 \mathrm{~min}$.

\section{Analysis of the consortium microbial profile by next- generation sequencing}

DNA isolation from the microbial consortium was performed using the commercial ZimoBiomics DNA kit (Zimo Research). The quality of the extracted DNA was examined by agarose electrophoresis (1\%) with ethidium bromide $(0.01 \%)$ and visualized under UV light. DNA samples were sent for analysis to LABSERGEN (CINVES TAV), where nuclear ribosomal internal transcribed spacer (ITS) region or $16 \mathrm{~S}$ amplicons were produced with 300,000 Paired End reads, and MiSeq sequences were generated. Bioinformatics analyses were carried out using readpipeline and MG_RAST [38]. The identification of the strains was conducted via massive BLAST [39] searches in MG_RAST [38], and the taxonomy of each strain was determined using the following databases: Encyclopedia of Life (http://www.eol.org/) [40], Global Catalog of Microorganisms (http://gcm.wfcc.info) [41], Integrated Taxonomic Information System (https:// www.itis.gov/) [42] and Livemap (http://lifemap-ncbi. univ-lyon1.fr/) [43].

\section{Inoculation process}

For the inoculation process, one gram of C. chinense cells (FW) were suspended in $25 \mathrm{~mL}$ of fresh MS medium and let to stand in the same cultivation conditions (at $25^{\circ} \mathrm{C}$ at $100 \mathrm{rpm}$ in continuous light) for 30 min prior to the cs addition. Inoculation was performed using different concentrations of the original cs $\left(1 \times 10^{1}\right.$, $1 \times 10^{4}$ or $1 \times 10^{8}$ ) under sterile conditions. These concentrations were chosen based on previous experiments reported with Colletotrichum [44]. Cells were harvested after specific periods of time (hours after infection or hai) for the different analysis that were performed; i.e. at 12, 24, and $48 \mathrm{~h}$ for morphological characterization; 1,3 , 6 and $12 \mathrm{~h}$ for transcript abundance or $6 \mathrm{~h}$ for lipid quantification. The cs concentration used for the morphological characterization, gene expression analysis and lipid analysis was $1 \times 10^{4}$ cells $/ \mathrm{mL}$.

\section{Epifluorescence analysis}

Suspension cells of $C$. chinense were infected (or not) with the consortium and washed three times with phosphate buffer saline (PBS) at $0.1 \mathrm{M}$ and $\mathrm{pH} 5.7$, and the suspension was diluted 1:10 in PBS. The cells were stained with the following dyes: $1 \mu \mathrm{M} \quad$ 4',6-diamidino-2-phenylindole dihydrochloride (DAPI) (Sigma) for nuclei; $1.76 \mu \mathrm{M}$ FM4-64 Dye ( $N$-(3triethylammoniumpropyl)-4-(6-(4-(diethylamino) phenyl) hexatrienyl) pyridinium dibromide) (Invitrogen ${ }^{\mathrm{TN}}$ ) for endoplasmic membrane; $10 \mu \mathrm{M}$ CellMask ${ }^{\mathrm{Tu}}$ Plasma Membrane Stain (Molecular Probes $\left.{ }^{\mathrm{s}}\right)$ for plasma membrane, and $2 \mu \mathrm{M}$ Calcofluor White Stain (WCF) (Fluka ${ }^{\mathrm{T}}$ ) for the cell wall. After $30 \mathrm{~min}$ of incubation at room temperature, fluorescence was observed via epifluorescence microscopy (Axioplan, Zeiss, Germany).

\section{Cell fixation and scanning electron microscopy}

For scanning electron microscopy (SEM), the MS medium was discarded, and $C$. chinense cells were washed with PBS (to eliminate any MS medium left) and incubated with $40 \%$ formaldehyde, 50\% ethanol, 5\% acetic acid, and 5\% distilled water (FAA solution) for 72 $\mathrm{h}$ at $25^{\circ} \mathrm{C}$ with gentle agitation every $3 \mathrm{~h}$. The samples were washed with PBS to eliminate the FAA solution. The cells were dehydrated in ethanol solutions in a sequential gradient of $30,50,70,96$, and $100 \%$ ethanol for $12,12,3,2$ and $1 \mathrm{~h}$, respectively. After the cells were fixed, the samples were dried to the critical point with liquid $\mathrm{CO}_{2}$ using a Sandri-795 critical point dryer (Tousimis), metalized with gold (Denton vacuum Desk II) and observed using SEM (JEOL JSM 6360LV).

\section{Cell viability assay}

C. chinense suspension cells infected with the consortium were washed 3 times with phosphate buffer, resuspended in $1 \mathrm{~mL}$ of PBS and gently mixed. Then, a 3-(4,5-dimethylthiazol-2-yl)-2,5-diphenyltetrazolium bromide (MTT) [45] (Sigma) solution was added to a final concentration of 0.5 $\mathrm{mg} \mathrm{mL}{ }^{-1}$, and the mixture was incubated at $25^{\circ} \mathrm{C}$ for $8 \mathrm{~h}$ in the dark. This method is a colorimetric assay that can be quantified on the basis of absorbance measurements. The ability of viable cells with active metabolism to convert MTT into formazan salts as a precipitate inside the cells was evaluated. MTT was solubilized with $1.5 \mathrm{~mL}$ of methanol solution ( $50 \%$ final concentration), and cells were incubated with this solution at $60^{\circ} \mathrm{C}$ for $30 \mathrm{~min}$. Finally, the cells were centrifuged at $1500 \mathrm{x}$ g for $5 \mathrm{~min}$. The supernatant was recovered, washed 5 or 6 times with methanol and mixed to determine the absorbance at $570 \mathrm{~nm}$.

\section{Protein extraction and quantification}

Frozen C. chinense cells, either previously infected or not, were pulverized in liquid nitrogen and homogenized with solution A (50 mM HEPES, pH 7.2, 0.25 M sucrose, $5 \mathrm{mM} \mathrm{KCl}$, and $1 \mathrm{mM}$ EDTA) with protease inhibitors $\left(1 \mu \mathrm{g} \mathrm{mL}^{-1}\right.$ leupeptin, $1 \mathrm{mM}$ phenylmethylsulfonyl fluoride (PMSF) and $1 \mu \mathrm{g} \mathrm{mL}^{-1}$ aprotinine) [46]. The extract was centrifuged at $20,000 \times \mathrm{g}$ for $30 \mathrm{~min}$ at $4{ }^{\circ} \mathrm{C}$, and the supernatant was centrifuged at $105,000 \mathrm{x} g$ for $1 \mathrm{~h}$ at $4{ }^{\circ} \mathrm{C}$. The obtained precipitate (membrane fraction) was resuspended in $200 \mu \mathrm{L}$ of $50 \mathrm{mM}$ HEPES, $\mathrm{pH}$ 7.4. The protein concentration in the extracts was determined with a modified bicinchoninic acid protein assay reagent [47], using bovine serum albumin (BSA) as a standard. 
The same conditions were used for protein extraction and quantification of the cs.

\section{Lipid kinase activity}

The activity of lipid kinases was determined on the basis of $\left[{ }^{32} \mathrm{P}\right] \gamma$-ATP incorporation into the corresponding endogenous substrate [48]. The phosphorylation assay was performed as reported by Racagni-Di Palma et al., [47] with minor modifications, using a reaction mixture with $50 \mathrm{mM}$ HEPES at pH 7.4, $1 \mathrm{mM}$ EDTA, $10 \mathrm{mM} \mathrm{MgCl}_{2}$, $1 \mathrm{mM}$ ATP, $0.2 \mathrm{mM}$ sodium vanadate, $0.5 \mathrm{mM}$ DTT, $\left[{ }^{32} \mathrm{P}\right] \gamma$-ATP $(370 \mathrm{MBq})$ and $80 \mu \mathrm{g}$ of membrane fraction proteins. The mixture was incubated for $2 \mathrm{~min}$ at $30^{\circ} \mathrm{C}$, and the reaction was finally stopped with $1.5 \mathrm{~mL}$ of chloroform:methanol $(1: 2, \mathrm{v} / \mathrm{v})$.

\section{Lipid extraction and separation}

Lipids were extracted and subjected to alkaline TLC to separate the different phospholipid species. Lipid extraction was conducted as described previously by RacagniDi Palma et al. [46]. In each sample, $0.5 \mathrm{~mL}$ of $2.4 \mathrm{~N} \mathrm{HCl}$ and $0.5 \mathrm{~mL}$ of chloroform were added, and the bottom phase was then carefully extracted and mixed with $2 \mathrm{~mL}$ of $1 \mathrm{~N}$ methanol: $\mathrm{HCl}(1: 1, \mathrm{v} / \mathrm{v})$. The lipids were dried under vacuum and resuspended in $200 \mu \mathrm{L}$ of chloroform:methanol $(9: 1, \mathrm{v} / \mathrm{v})$. Finally, the lipids were analyzed using thin layer chromatography (TLC) plates impregnated with solution I [ $1 \%$ potassium oxalate, 2 mM EDTA, and methanol:water $(2: 3, \mathrm{v} / \mathrm{v})]$ and activated for $40 \mathrm{~min}$ at $110^{\circ} \mathrm{C}$. The plates were developed with solutions of chloroform:methanol:acetone:acetic acid:water (40:15:14:12:7, v/v) and chloroform:pyridine:formic acid $(35: 30: 7, \mathrm{v} / \mathrm{v})$ for the first and second dimensions of TLC, respectively [46]. The positions of the radiolabeled lipids were determined by autoradiography.

\section{Phylogenetic analysis}

Phylogenetic testing was conducted on DGK proteins using complete amino acid sequences obtained from the SOL Genomics Network database (https://www.sgn. cornell.edu/) [49]. The sequences were aligned using ClustalW [50] and displayed with MEGA 6 [51] software, and the maximum likelihood method was employed with a robustness of 1000 bootstrap replicates. The C. chinense DGK homologs DGK1, DGK2, DGK3, $D G K 5, D G K 5 L, D G K 6$ and DGK7 were tested against the predicted proteins from tomato (S. lycopersicum ITAG release 2.4), coffee (C. canephora v1.0) and Arabidopsis to obtain their phylogenetic relationships.

\section{Gene expression assay and data analysis}

Cultured cells of $C$. chinense were infected for $1,3,6$ and $12 \mathrm{~h}$ with $1 \times 10^{4} \mathrm{cs}$, and the consortium was analyzed. For the expression analysis, RNA was isolated using TRIZol ${ }^{\mathrm{TM}}$ RNA Reagent (Invitrogen ${ }^{\mathrm{TM}}$ ), and cDNA was synthesized using $500 \mathrm{ng}$ of the total RNA with Revert Aid Reverse Transcriptase (Thermo Scientific). For the reverse transcription-quantitative polymerase chain reaction (RT-qPCR) assays, amplification was conducted using Maxima SYBR Green/ROX qPCR Master Mix (Thermo Scientific) and a PikoReal 24 real-time PCR system (Thermo Fisher Scientific, Ratatsie 2, FI-01620 Vantaa, Finland). The conditions for RT-qPCR were as follows: 1) initial denaturation step at $95^{\circ} \mathrm{C}$ for $10 \mathrm{~min}$; 2) two-step cycling at $95^{\circ} \mathrm{C}$ for $40 \mathrm{~s}$ and Tm for $40 \mathrm{~s}$ with 40 or 45 cycles for each gene; and 3 ) final melting curve step from $56^{\circ} \mathrm{C}$ to $95^{\circ} \mathrm{C}$. The primers used were designed based on pepper genome sequences ( $C$. annuum cv. CM334 genome CDS) and tested in $C$. chinense as CchDGK1, CchDGK3, CchNPC6, CchPR1a, CchPR5, CchTUBa and CchEF2a3L, respectively (Table S1). Finally, for fold change determination, a $2^{-\Delta \Delta}$ CT method with an individual efficiency corrected calculation was used [52], CchTUBa and CchEF2a3L were used as a reference genes.

\section{Results}

\section{Analysis of the consortium microbial profile}

The isolated consortium from the rotten roots of C. chinense seedlings was characterized by NGS to identify the microorganisms present. The metadata were stored in the NCBI database with the registration number ID PRJNA479448. The bioinformatics analysis of the sequences enabled the identification of the microorganisms present in this consortium, with $C$. ignotum accounting for most of the eukaryotic microorganisms present (Fig. S1), while the predominant genus of prokaryotes was Bacteroides (Fig. S2), such as Barnesiella sp.,Alistipessp, Pantoea sp., Acinetobacter sp., Parabacteroides, Kluyveromyces marxianus, Galactomyces geotrichum, Glomus sp., Exophiala sp., Malassezia restricta, Postia placenta, Elmerina caryae, Faecalibacterium, Clostridium IV, Halanaerobium, Veillonella, Phascolarctobacterium, Phascolarctobacterium, Lachnospiracea, Roseburia, Desilfonatronovibrio, Streptococcus, (less than 3\%; S1) The low proportion of reads obtained from $16 \mathrm{~S}$ compared to those obtained from the ITS amplicon does not limit their relationship with the plant or with the majority strain. Thus, we consider the set of identified microorganisms as a consortium.

\section{Infection establishment}

To understand the relationship between host and pathogen, $C$. chinense suspension cells were inoculated with the microbial consortium primarily consisting of C. ignotum. First, we started by determining the infection conditions and sampling times that resulted in a contrasting response at the morphological level, growth rate and/or 
exacerbation of death and could therefore provide more information regarding the topic investigated.

C. chinense cells that were infected with a $1 \times 10^{8} \mathrm{cs}$ (empty triangles) showed a decrease in viability of approximately $35 \%$ after $12 \mathrm{~h}$ and decreases of up to 50 and $90 \%$ at 24 and $48 \mathrm{~h}$ after inoculation, respectively (Fig. 1 a). Under treatment with a $1 \times 10^{4}$ cs (filled triangles), decreases of approximately 15,30 and $40 \%$ were observed at 12, 24 and $48 \mathrm{~h}$ after inoculation, respectively, whereas when cells were inoculated with a $1 \times 10^{1}$ cs (open circles), a clear trend was not obtained (Fig. 1 a). The decrease in viability was also correlated with a decrease in fresh weight (Fig. 1 b). When the cells were exposed to the most concentrated cs, a greater decrease in viability as well as in fresh weight were observed $(1 \times$ $\left.10^{8} \mathrm{cs}\right)$. Finally, a $1 \times 10^{4} \mathrm{cs}$ allowed us to generate slight (30\%) and/or severe cell damage (50\%) after 24 and $48 \mathrm{~h}$ of treatment, respectively.

Images of $C$. chinense suspension cells in the presence of the microbial consortium showed an expanded cell phenotype after $24 \mathrm{~h}$ and a clearer phenotype at $48 \mathrm{~h}$ after inoculation compared to the control cells (Figs. 2, 3). Interestingly, when a viable consortium was compared with the attenuated version, these two consortia exhibited the same response to a blow-up cell phenotype (Fig. 2). Finally, at $48 \mathrm{~h}$ after the inoculation of a $1 \times 10^{8} \mathrm{cs}$, the cell culture presented a dark brown color and null viability (data not shown).

With respect to the pathogens, the consortium showed a notable amount of growth after $12 \mathrm{~h}$; major changes in hyphal abundance were observed at $48 \mathrm{~h}$ after inoculation when a $1 \times 10^{4}$ cs was used (Figs. 2, 3) and increased hyphal abundance was observed when a $1 \times 10^{8}$ cs was used (data not shown).

\section{Morphological changes during infection}

C. chinense suspension cell morphology was evaluated after the cells were inoculated after 24 and $48 \mathrm{~h}$ with a $1 \times 10^{4} \mathrm{cs}$ from the microbial consortium. At $24 \mathrm{~h}$ after inoculation, the cells showed changes such as increased cell turgidity and a low abundance of hyphae in C. chinense cells and the microbial consortium, respectively (Fig. 3). Some C. chinense cells began to exhibit disruption when inoculated with a $1 \times 10^{8} \mathrm{cs}(6 \mathrm{~h}$ after treatment, data not shown).

On the other hand, the cells were evaluated using fluorophores to observe the cell wall (WCF), cytoplasmic membrane (CellMask), endoplasmic membrane (FM464) and DNA integrity (DAPI; Fig. 4). During the experiments without the consortium, the structure of the $C$. chinense cells remained unchanged even 24 to $48 \mathrm{~h}$ after mock inoculation (non treated cells) (MS medium) (Fig. $4)$. When the $C$. chinense cells were inoculated, they showed damage to the plasma and endoplasmic reticulum membranes even $12 \mathrm{~h}$ after inoculation (Fig. 4). However, at $48 \mathrm{~h}$ after inoculation, the damage to both membranes (plasma and endoplasmic) and the cell wall was severe (Fig. 4).

The evaluation of DNA integrity with DAPI showed that prior to $24 \mathrm{~h}$ after inoculation, the cells accumulated moderate DNA damage, and DNA aggregation and fragmentation were observed at $48 \mathrm{~h}$ (Fig. 4).
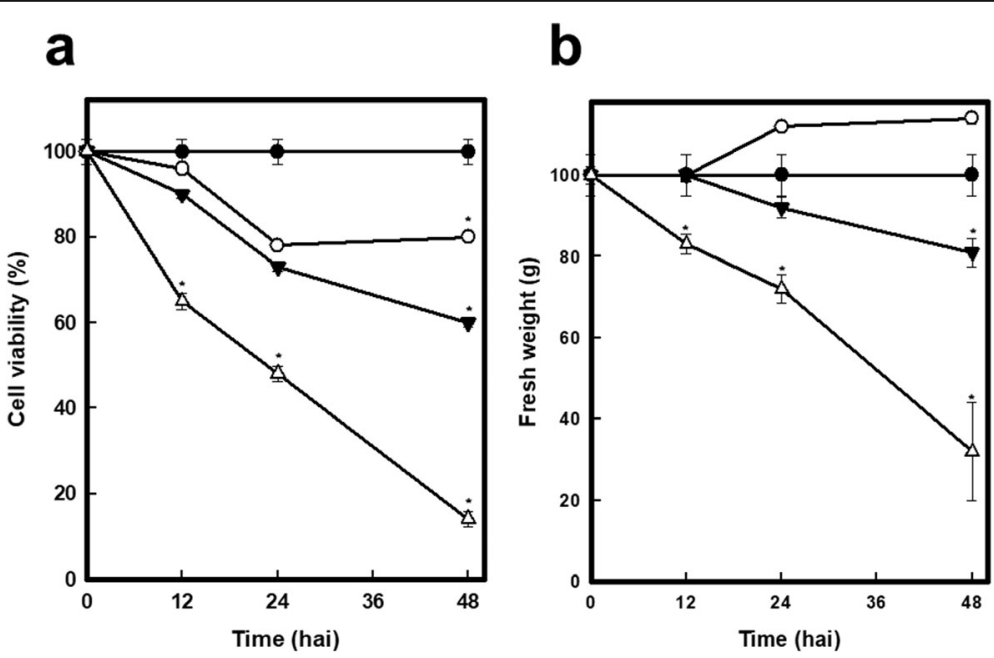

Fig. 1 Evaluation of the optimal infection time using C. chinense cells infected with cs. a) Cells were infected with different amounts of cs $\left(1 \times 10^{8}=\right.$ white triangles, $1 \times 10^{4}=$ black triangles, $1 \times 10^{1}=$ white circles) from the consortium and incubated for different times (hours after infection, hai). Cells without treatment are indicated in black circles. Cell viability was determined using MTT. b) Fresh weight of the cells after the infection treatments. Values are the means of three experiments with triplicates $+/-\mathrm{SE},{ }^{*} p<0.05$ 
a

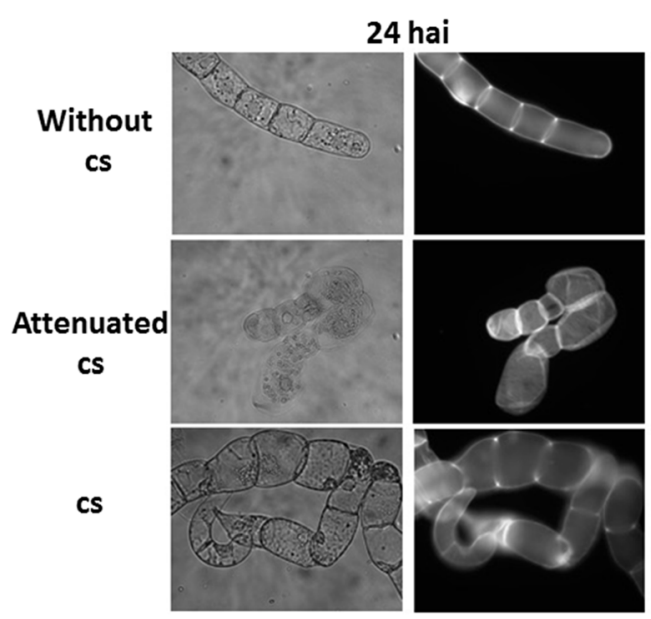

b

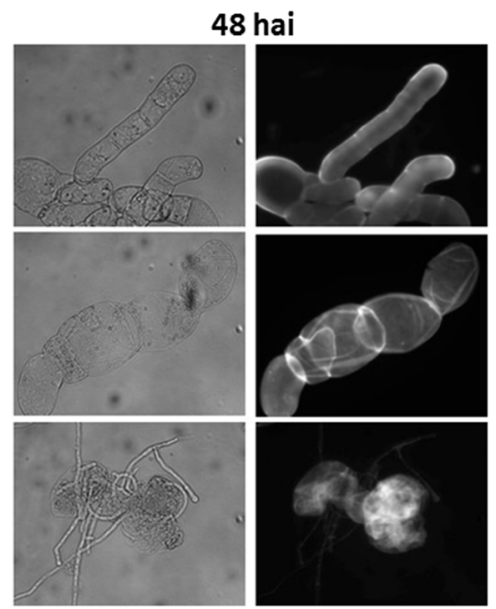

Fig. 2 Morphological structure of C. chinense cells after infection with a cs. The cells (1 g) were treated for 24 (a) and 48 hai (b) without the cs, with the attenuated cs and with the unattenuated cs $\left(1 \times 10^{4}\right)$, then stained with WCF and visualized using epifluorescence microscopy. The figures are representative of three independent experiments, with two images from each obtained via microscopy

\section{Changes in lipid kinase activity are involved in infection events}

The effect of the microbial consortium on phospholipidderived molecules in C. chinense cells was evaluated. Cells were incubated for $6 \mathrm{~h}$ in the presence or absence of the consortium $\left(1 \times 10^{4} \mathrm{cs}\right)$. Lipid kinase activities were assayed. We observed that at 6 hai, the levels of PA, lysophosphatidic acid (LPA) and DGPP were higher in inoculated cells than in untreated cells (Fig. 5).

Next, the transcription profiles of DGK genes during infection events were analyzed and a phylogenetic test was conducted. In an in silico search, at least 7 DGK homologs (CanDGK1, CanDGK2, CanDGK3, CanDGK6, CanDGK6-L, CanDGK6-L2 and CanDGK7) were found in the C. annuum genome (C. annuum cv CM334 genome CDS). These well annotated sequences were employed to guarantee that the designed primers would be used to find functional genes (Fig. S3).

Expression levels of genes for DGK homologs (CchDGK1 and CchDGK3), a nonspecific PLC (CchNPC6) and also genes related to pathogenesis, such as PR (CchPR1a and CchPR5) were monitored at several infection stages up to 12 hai, given that at this time, the cells showed morphological changes without exhibiting extensive damage or cell death. CchDGK1 and CchDGK3 genes showed maximal increases in transcript abundance within the first hour after inoculation, and they maintained augmented expression for up to 12 hai when C. chinense

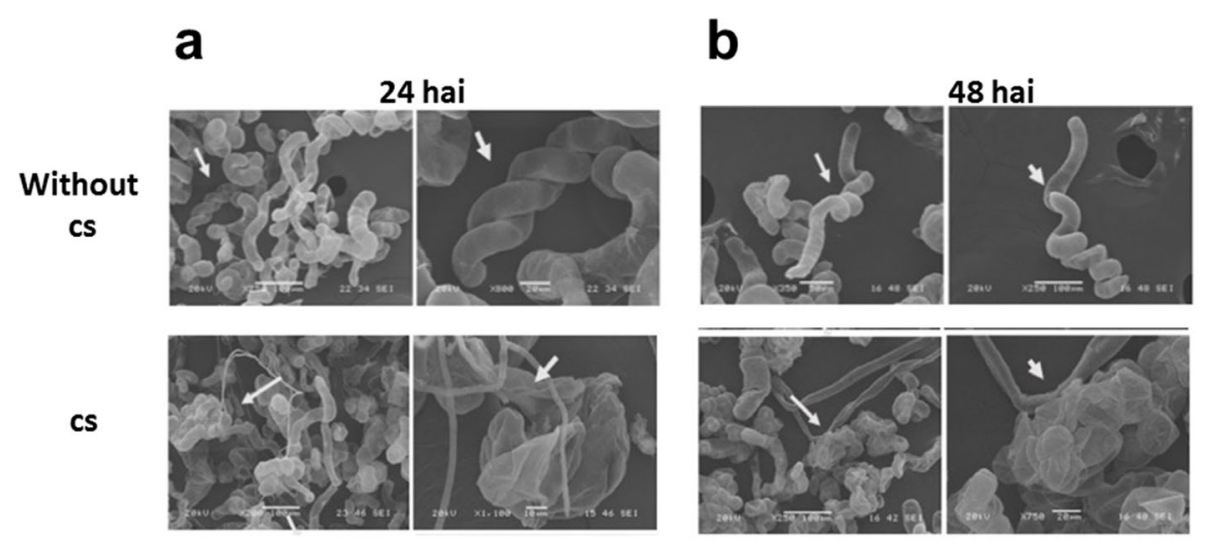

Fig. 3 Morphological effects of cs treatment. The cells were treated for $24(\mathbf{a})$ and 48 hai $(\mathbf{b})$ without or with the cs $\left(1 \times 10^{4}\right)$. The cells were observed using SEM. The figures are representative of three independent experiments with two images from each obtained via SEM (white arrows are pointing to $C$. chinense cells) 


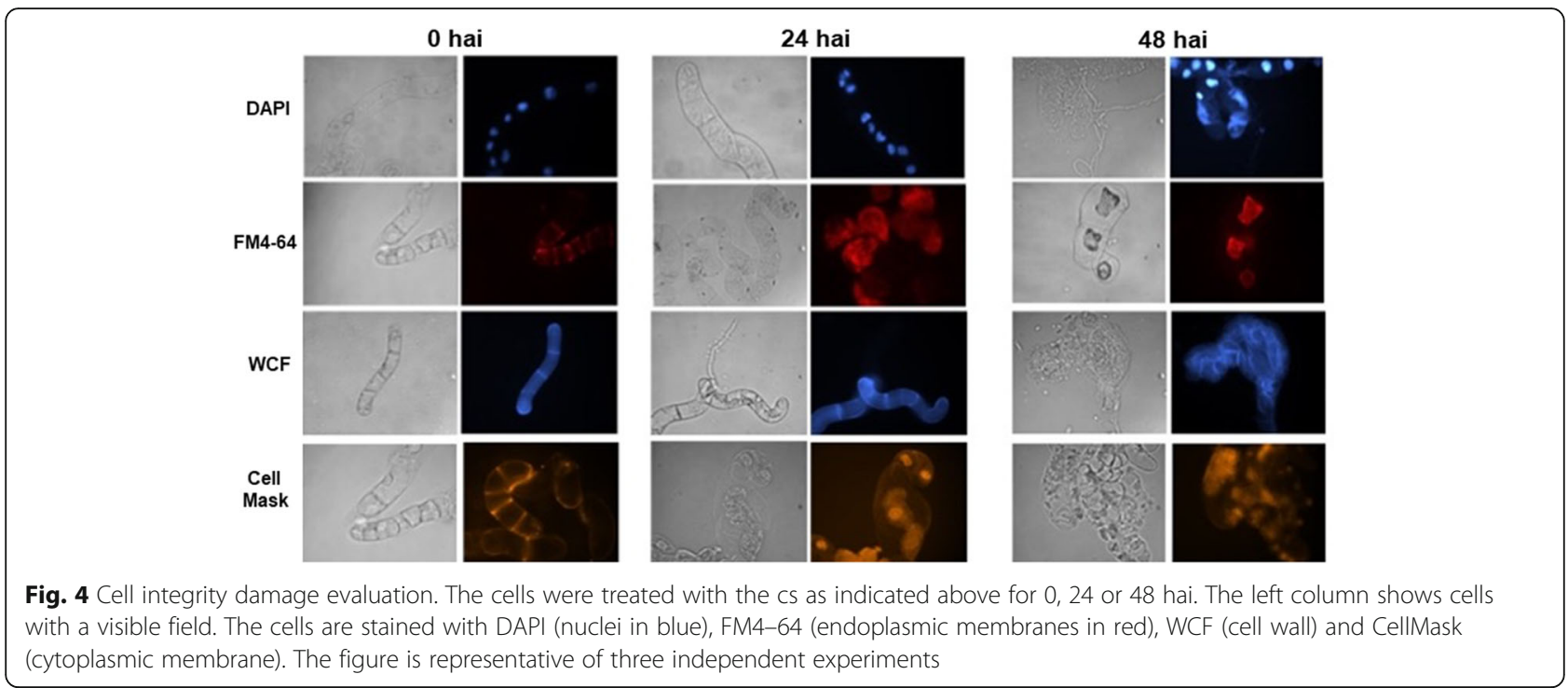

suspension cells were challenged with a $1 \times 10^{4}$ cs (Fig. 7). In non-treated cells, both CchDGK1 and CchDGK3 showed an important repression after 1 hai (Fig. 7). Regarding the pathogenesis related genes, both CchPR $1 a$ and CchPR5 genes, were repressed after 1 hai. In addition, both genes showed augmented expression up to 12 hai, but in lower levels than the DKG homologs (Fig. 8). CchPR1a and CcPR5 in non-treated cells showed a minor repression during the first 12 hai (Fig. 8). It is noteworthy to mention that CchNPC6 also presented a moderated increase after 1 hai, to decrease subsequently (Fig. 8).

The phylogenetic assays for DGK from plants showed 3 well-defined groups. The first one included DGK1 and DGK2 (Fig. S3, in blue); the second included DGK3 and
DGK7 (Fig. S3, in green); and DGK6, DGK6-L and DGK6-L2 were in the final group (Fig. S3, in red).

\section{Discussion}

A plethora of mechanisms of interaction between plants and pathogenic microorganisms has been reported by several authors; however, to reproduce those interactions that occur in the field in our study model, we had to consider that the roots of plants interact with consortia of microorganisms to obtain a broader view of plantmicrobiome relationships. In the present work, we isolated a consortium, which was then characterized by metagenomic analysis and applied to a cellular model of C. chinense, allowing us to observe cell signaling

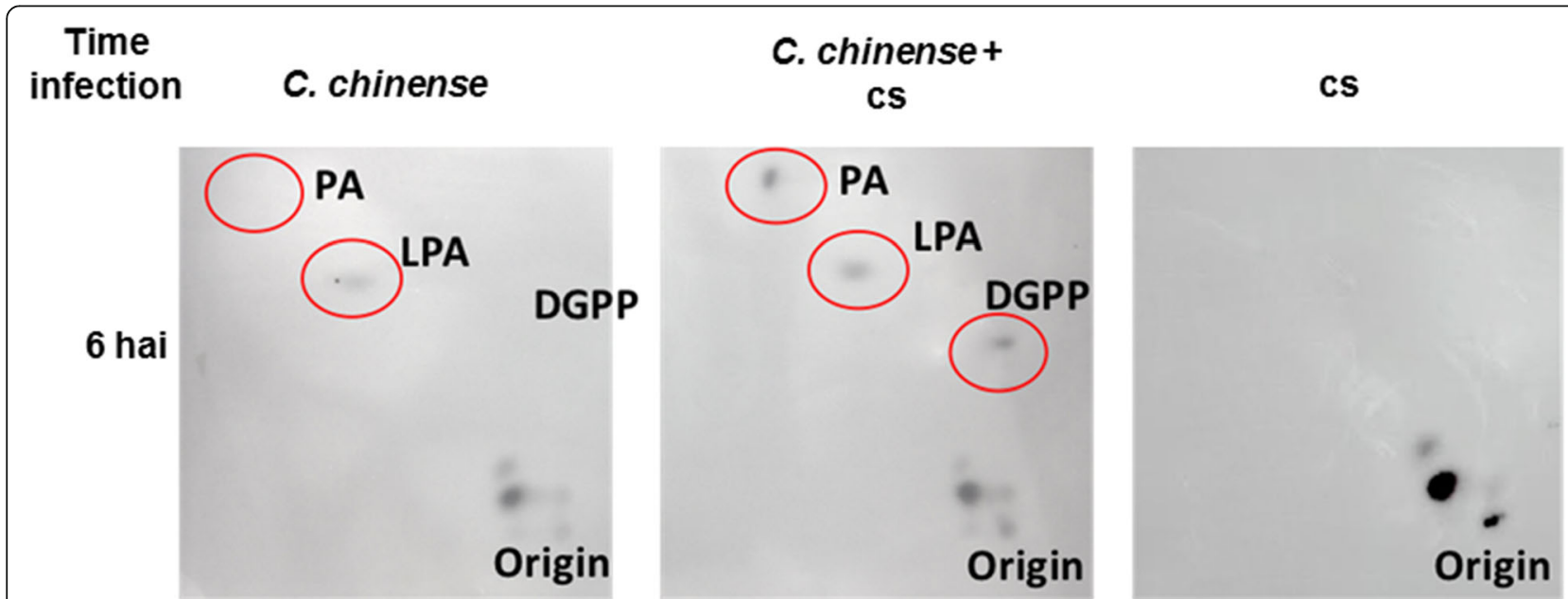

Fig. 5 Detection of lipids produced by kinase activity using 2D-TLC. Lipids from C. chinense cell cultures infected for $6 \mathrm{~h}$ with a cs $\left(1 \times 10^{4}\right)(C$. chinense + cs) were subjected to alkaline TLC to separate the different phospholipid species. As a control, lipids were developed from only C. chinense cells or only the cs. Radioactivity was detected by autoradiography. A representative result from three experiments is presented 
activated by this interaction. Metagenomics revealed that the major microorganism present was Colletotrichum ignotum, which is related to anthracnose disease in fruits [53].

In the in vitro infection system established in this study, all $C$. chinense cells grown in suspension exhibit the same probability of infection. Defined amounts of cs can be added to a standardized amount of $C$. chinense cells, and the infection can be followed by microscopy at different times (Figs.2, 3 and 4). Shortly after inoculation, primary infection was observed with the penetration of the hyphae into the cells and effects due to infection, such as the deterioration of the cell wall and a collapse of the plasma membrane followed by a stage in which fragmentation of the nuclei, can be observed (Figs. 3 and 4). The disruption of cells could be caused by programmed cell death in response to inoculation with the consortium. In contrast, after $48 \mathrm{~h}$ of inoculation, a complete reversal of the ratio of the plant cell vs hyphae populations occurred, and $C$. chinense cells died when the microbial consortium reached the largest hyphal population (Fig. 3).

Damage to the cell wall may result from the secretion of cellulases and pectinases that degrade the cell wall by the cs which, along with proteases, facilitates the initial penetration and infection of the host. In 2004 [54], Kim and collaborators observed nuclear changes and structural changes related to an hypersensitivity response in the fruit of Capsicum annuum cv. Jejujaerae (susceptible) and Capsicum baccatum cv. PBC80 (resistant) inoculated with the anthracnose pathogen Colletotrichum gloeosporioides, where degradation of the cell wall by enzymes secreted by the pathogen was observed. In addition, the separation of the plasma membrane from the cell wall, the swelling of the endoplasmic reticulum, the accumulation of dense inclusions in the vacuoles and cytoplasmic vacuolization accompanying fragmentation of the cytoplasm and DNA fragmentation were observed. Therefore, our results suggest that cell wall damage is a characteristic of pathogen attack (cs) in the cell suspension model of $C$. chinense.

Naton and colleagues [55] observed a reduction in cell viability and changes in the morphology of cell suspensions of parsley during infection with Phytophthora infestans. These changes in cells during infection are due to the formation of reactive oxygen species, particularly the highly aggressive oxygen radicals that produce lipid peroxidation $[56,57]$. The effect of cs in $C$. chinense generated an increase in cell death that became evident over time.

In this study, the structural damage observed in the cells of C. chinense (Figs. 3 and 4) could be derived from various biochemical events occurring primarily in the plasma membrane. For example, unsaturated fatty acids can be oxidized and eliminated from the lipid bilayer since $\operatorname{ROS}\left(\mathrm{H}_{2} \mathrm{O}_{2}\right)$, which are generated as an initial response of cells to attack by a pathogen, can trigger the activation of lipoxygenases [57, 58].

In plants, PA and DGPP are well accepted as second messengers in signaling pathways and respond to biotic and abiotic stress [19, 22, 59-62]. As mentioned before, high levels of PA were found when $C$. chinense suspension cells were inoculated with a microbial consortium that primarily consisted of C. ignotum. Many authors have reported that PA is subsequently metabolized to DGPP in response to many types of biotic or abiotic stress, such as pathogens [21] water deficits [59], fungal elicitors [22], osmotic stress [63], Nod factors [64], and salt stress [65].

In plants, the phosphorylated forms of PA and DGPP have started to gain importance as signaling molecules involved in many stress responses [66]. Here, we report the presumptive activity of the PI-PLC/DGK phospholipid pathways and the phospholipid-derived molecules resulting from PIP or $\mathrm{PIP}_{2}$ hydrolysis forming second messengers, such as PA and DGPP, which eventually invoke downstream signaling responses to infection. In general, the detected PA could be obtained via two different pathways: one involving PLD, which generates PA directly by hydrolyzing structural phospholipids such as phosphatidylcholine (PC), while the other involves PIPLC, which generates DAG, and DAG is subsequently phosphorylated to PA via the action of PLC/DGK [67] (Fig. 6). However, increasing evidence points to PA accumulation in relation to PI-PLC/DGK activity in response to pathogen effectors such as bacterial elicitors $[22,68]$, specific effectors from Pseudomonas syringae [69] and fungi, such as Cladosporium fulvum [67] and Botrytis cinerea [70]. In this manner, perhaps PA resulting from PLC/DGK activity could be produced via PIP conversion in the first stages of infection $(6 \mathrm{~h}$ after inoculation).

PA may resulted in $\mathrm{PIP}_{2}$ conversion by PI-PLC activity, either via the direct hydrolysis of $\mathrm{PIP}_{2}$ or the initial transformation of PIP to PIP $_{2}$ via the activity of a phosphatidylinositol 4-phosphate 5 kinase (PIP5K) (Fig. 6) [71-73]. However, the levels of LPA (Fig. 5) did not show significant changes compared to those in control cells, and/or minor changes could be generated by phospholipase A (PLA) activity through a route that may involve the turnover of PA (Fig. 6). On the basis of all of these data, we hypothesized that the increase in PA resulted in coordinated action between the PI-PLC/DGK pathways.

When these biochemical changes were contrasted to the DGK transcription profile during infection events, a correlation between PA or DGPP accumulation and the specific expression of DGK (CchDGK1 and CchDGK3) 


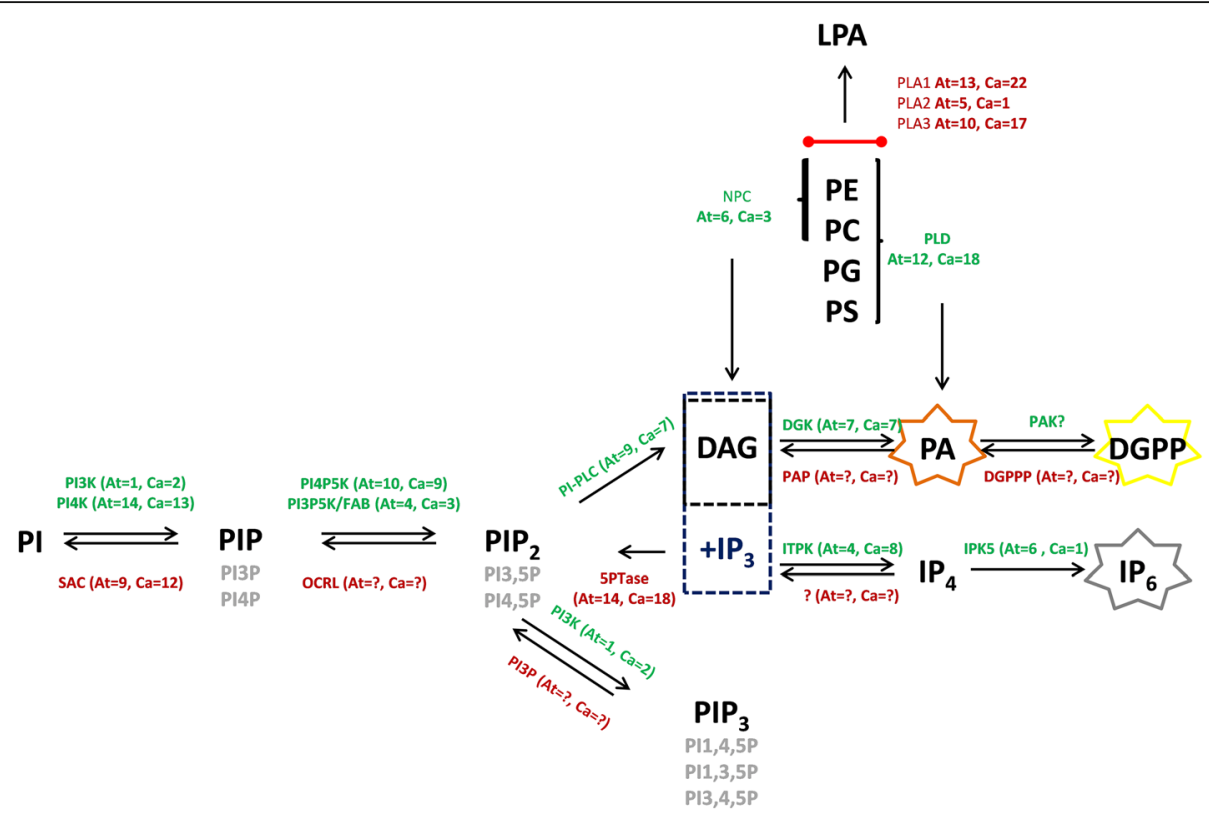

Fig. 6 Production of PA and DGPP by different pathways and interconversion reactions mediated by phosphorylation and dephosphorylation. Green denotes phosphorylation reactions, and red denotes dephosphorylation reactions. Other colors indicate key enzymes in these pathways. In the phosphorylation pathway: PI3K or PI4K, phosphatidylinositol 3-kinase or 4-kinase, respectively; PI4P5K, phosphatidylinositol 4phosphate 5-kinase; PI3P5K, phosphatidylinositol 3-phosphate 5-kinase; ITPK, inositol-tetrakisphosphate 1-kinase; IPK5, inositol-pentakisphosphate 2kinase and DGK, diacylglycerol kinase. In the dephosphorylation pathway: PAP, phosphatidic acid phosphatase; 5PTase, inositol polyphosphate 5phosphatase; PI3P phosphatidylinositol 3-phosphatase and PI5P, phosphatidylinositol 5-phosphatase. Key enzymes: PLD, phospholipase D; NPC, nonspecific phospholipase C; PI-PLC, phosphatidylinositol-specific phospholipase C and PLA, phospholipase A. PI, phosphatidylinositol; PIP, phosphatidylinositol phosphate; $\mathrm{PIP}_{2}$, phosphatidylinositol bisphosphate; PIP 3 , phosphatidylinositol trisphosphate; DAG, diacylglycerol; PA, phosphatidic acid; DGPP, diacylglycerol pyrophosphate; IPx, inositol polyphosphates; PC, phosphatidylcholine; PE, phosphatidylethanolamine; PG, phosphatidylglycerol and PS, phosphatidylserine

was obtained, in which the results showed the highest accumulation of transcripts after 1 to $12 \mathrm{~h}$ of inoculation (Fig. 7) and were consistent with the analysis of marker genes related to pathogenesis (CchPR1a and CchPR5, Fig. 8), when $C$. chinense suspension cells were challenged with the microbial consortium. These results support the hypothesis that higher DGK transcript accumulation could be related to PA-DGPP levels in infection events between $C$. chinense suspension cells and the microbial consortium. These data support the notion that higher levels of PA can be produced by the activity of DGK in the phosphoinositide pathway in C. chinense suspension cells in response to infection events. Based on the results (activity and gene expression), it is probable that DGK seems to be involved in the signaling events of this pathogen. However, we would not exclude the possibility that the other enzymes (and genes) shown in Fig. 6 are also involved in this process. Furthermore, three PLCs and four PLDs were also analyzed in this study, and we did not observe an increase in gene expression at the times tested (data not shown).

However, expression of a gene for a non-specific PLC, such as CchNPC6, exhibited an important increase only at very short times (at 1 hai) and basal levels thereon
(Fig. 8), probably pointing to a generalized response to cell culture manipulation. In contrast, DGKs expression maintained higher levels after 3, 6 and $12 \mathrm{~h}$ following inoculation, whereas CchNPC6 was greatly reduced at those same times (Fig. 7). Pathogenesis-related genes, specifically CchPR5, presented a similar behavior to that of DGKs, increasing within the first hour to be reduced at 3 or $6 \mathrm{~h}$ and then increase again (12 hai, Fig. 8). This pattern demonstrates that the response observed in the beginning corresponds to a generalized response, while at $12 \mathrm{~h}$, it changed to a specific response to the microbial consortium (Fig. 8).

Recently, Gonorazky et al. [70] demonstrated that the PLC/DGK pathway is required to regulate defense responses to the necrotrophic pathogen $B$. cinerea by transiently silencing SIPLC2 in tomato plants. Zhang et al. [74] reported that the overexpression of rice DGK in tobacco enhances resistance to Phytophthora parasitica var. nicotianae and that the increase in the accumulation of PA confers disease resistance.

\section{Conclusions}

This study demonstrated the activation of the phospholipid signaling pathway in response to a microbial 


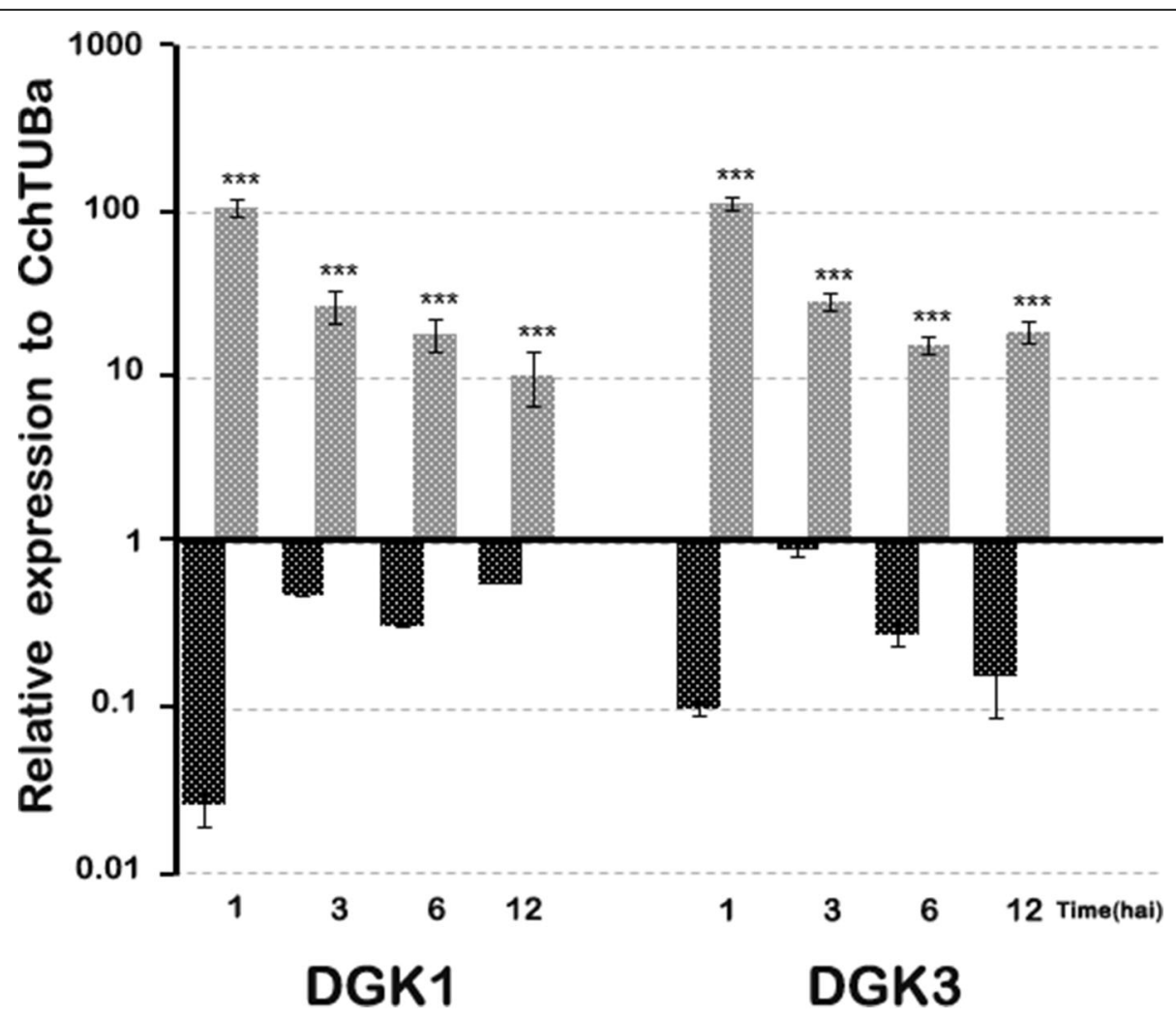

Fig. 7 CchDGK transcription level during cs infection events. C. chinense cells were infected with a $1 \times 10^{4} \mathrm{cs}$ for different time periods (hai), RNA was extracted, and the relative expression of CchDGK1 and CchDGK3 was analyzed through real-time quantitative PCR. The gene expression was calculated taken as a reference gene CchTUBa and CChEF2a3L, (black bar) non treated cells, (grey bar) cells plus cs. Data from three independent experiments with three biological samples run in duplicate are presented as the mean $+/-\mathrm{SE}_{1}{ }^{* *} p<0.001$

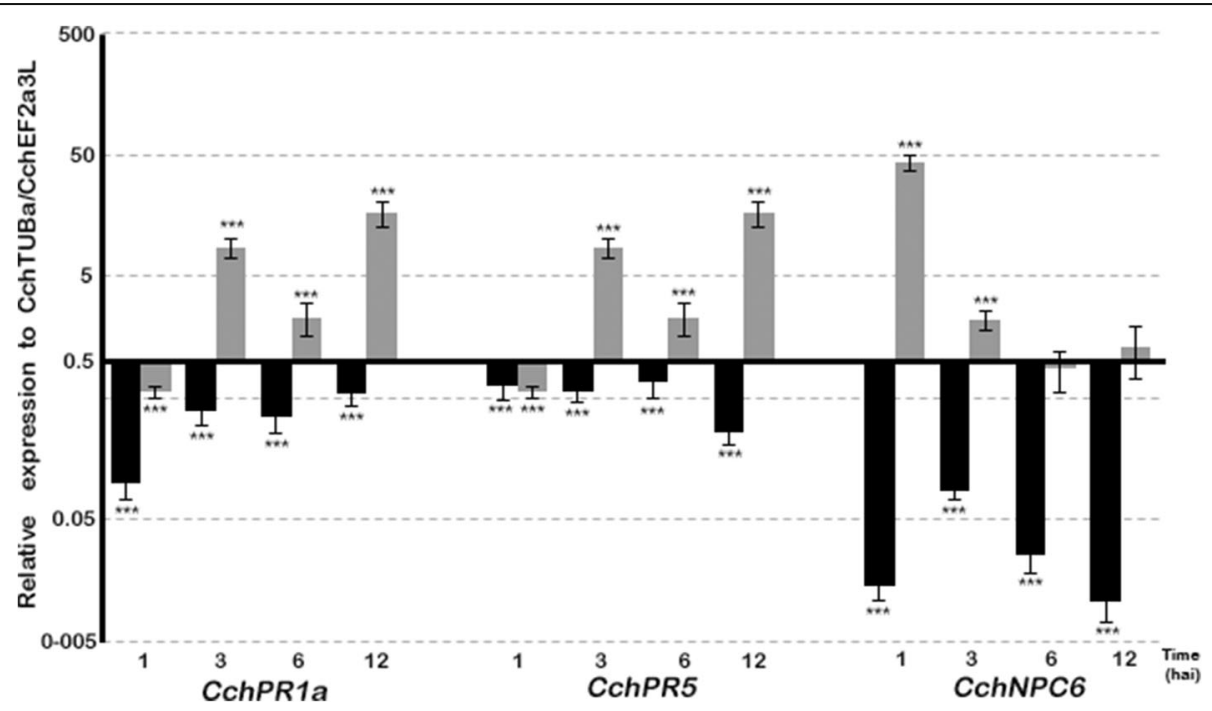

Fig. 8 Pathogenesis-related genes and NPC6 transcription levels during cs infection events. C. chinense cells were infected with a $1 \times 10^{4} \mathrm{cs}$ for different time periods, after which RNA was extracted, and the relative expression of pathogenesis-related transcripts (CchPR1a and CchPR5) and CchNPC6 was analyzed through RT-qPCR taken as a reference gene CchTUBa and CchEF2a3L, (black bar) non treated cells, (grey bar) cells plus cs. Data from three independent experiments with three biological samples run in duplicate are presented as the mean $+/-\mathrm{SE}^{*}{ }^{* *} p<0.001$ 
consortium. Also, expression of DGKs, as well as that of some others related to pathogenesis, was affected in the presence of the consortium. The presence of the consortium also induced membrane disruption and important reduction in cellular viability. The next step in the research will be the use of phospholipases and kinases inhibitors to distinguish the contribution of each pathway to the microbial consortium response. The study of transcriptomics to detect gene clusters activated differentially by the microbial consortium and by other activation pathways of the phospholipid signal cascade is also contemplated. In future works, we intend to extend our research to determine the types of consortia formed in the cultivation fields and the correlation in the response capacity and development of the plant.

\section{Supplementary Information}

The online version contains supplementary material available at https://doi. org/10.1186/s12870-021-02830-z.

Additional file 1: Supplementary Fig. S1. Relative abundance of species of fungi; only Colletotrichum ignotum showed $>1 \%$ abundance

Additional file 2: Supplementary Fig. S2. Relative abundance of bacterial populations; only genera with a relative abundance $>1 \%$ are shown

Additional file 3: Supplementary Fig. S3. Phylogenetic tree of $C$. chinense DGK. The phylogeny was reconstructed based on the alignment of the predicted protein sequences from pepper (Ca), tomato (Sol), coffee (Cc) and Arabidopsis (At). The tree was produced using the maximum likelihood method, conducting testing with 1000 bootstrap replicates, and was displayed using MEGA 6 . The numbers at the nodes are the bootstrap values (> 10\%), and the branch lengths from the root are displayed.

Additional file 4: Supplementary Fig. S4. Melting curves by CchDGK3 and CChPRIa

Additional file 5: Supplementary Fig. S5. Melting curves by CChEF2a3L and CchDGK1.

Additional file 6: Supplementary Fig. S6. Melting curves by CchPR5 and CChNPC6.

Additional file 7: Supplementary Fig. S7. Melting curves by CChTUBa. Additional file 8: Supplementary Fig. S8. 2D-TLC-autoradiography from lipids from C. chinense cell cultures.

Additional file 9: Supplementary Fig. S9. 2D-TLC-autoradiography from lipids from $C$. chinense cell cultures infected for $6 \mathrm{~h}$ with a cs $(1 \times$ $\left.10^{4}\right)$.

Additional file 10: Supplementary Fig. S10. 2D-TLC-autoradiography from lipids from cs $\left(1 \times 10^{4}\right)$.

Additional file 11: Table S1. Primers sets from C. chinense in references with C. annuum homologs

\footnotetext{
Abbreviations

cs: conidial suspension; DAG: diacylglycerol; DAPI: 4',6-diamidino-2phenylindole dihydrochloride; DGK: diacylglycerol kinase; DGPP: diacylglycerol pyrophosphate; DTT: Dithiothreitol;

EDTA: Ethylendiaminetetraacetic acid; FAA solution: 40\% formaldehyde, 50\% ethanol, 5\% acetic acid, and 5\% distilled water; FM4-64: (N-(3Triethylammoniumpropyl)-4-(6-(4-(Diethylamino)Phenyl) Hexatrienyl Pyridinum Dibromide); hai: hours after infection; HEPES: 2-[4-(2hydroxymethyl)piperazin-1-yl] ethanesulfonic acid; 5PTase: inositol polyphosphate 5-phosphatase; ITS: internal transcribed spacer; IPx: inositol polyphosphates; IPK5: inositol-pentakisphosphate 2-kinase; ITPK: inositol-
}

tetrakisphosphate 1-kinase; JA: Jasmonic Acid; LPA: Lysophosphatidic acid; MJ: Methyl Jasmonate; MS: Murashige and Skoog medium; MTT: 3-(4,5dimethylthiazol-2-yl)-2,5-diphenyltetrazolium bromide; NPC: nonspecific phospholipase C; PA: phosphatidic acid; PAP: phosphatidic acid phosphatase; PBS: sodium phosphate buffer; PC: phosphatidylcholine; PE: phosphatidylethanolamine; PG: phosphatidylglycerol; PI: phosphatidylinositol; PIP5K: phosphatidylinositol 4-phosphate 5 kinase; PI3K: phosphatidylinositol 3-kinase; PI4K: phosphatidylinositol 4-kinase; PI3P: phosphatidylinositol 3-phosphatase; PI5P: phosphatidylinositol 5phosphatase.; PI4P5K: phosphatidylinositol 4-phosphate 5-kinase; PI3P5K: phosphatidylinositol 3-phosphate 5-kinase; PIP: phosphatidylinositol phosphate; $\mathrm{PIP}_{2}$ : phosphatidylinositol bisphosphate; $\mathrm{PIP}_{3}$ : phosphatidylinositol trisphosphate; PLA: Phospholipase A; PI-PLC: Phosphatidylinositol-specific phospholipase C; PLD: Phospholipase D; PMSF: phenylmethylsulfonyl fluoride; PS: phosphatidylserine; ROS: Reactive Oxygen Species; RT-pPCR: reverse transcription-quantitative polymerase chain reaction; SEM: Scanning Electron Microscopy; SA: Salicylic Acid; TLC: Thin Layer Chromatography

\section{Acknowledgments}

We would like to acknowledge technical assistance from Angela Kú González and I.Q. Silvana Andrade Canto, which was greatly appreciated.

\section{Consent to publish}

Not applicable.

\section{Authors' contributions}

MS, GR, VG, AR and TH conceived and designed the experiments, performed the experiments, analyzed the data, and prepared figures and/or Tables. YC performed the experiments. JM performed the experiments, analyzed the data, and prepared figures and/or tables. All authors reviewed the draft of the paper and approved the manuscript.

\section{Funding}

Our research was supported by a Consejo Nacional de Ciencia y Tecnología (CONACYT) grant (Grant IFC 035/2015) awarded to SMTH-S. The funding agent only provided the financial support or reagents, field trips and a postdoctoral fellowship and did not involve in the design of the experiment, collection, interpretation and analysis of data and in drafting the manuscript. Also a (CONACYT) scholarship (166897) awarded to VMG for a postdoctoral training.

\section{Availability of data and materials}

All data generated in this study are included in the paper and in the supporting information files. Metagenomic data are available at https://doi. org/10.17632/mmd6f2v9z8.1. Biological materials used in the present study are available from the corresponding author upon reasonable request.

\section{Ethics approval and consent to participate}

Not applicable.

\section{Competing interests}

The authors declare that they have no competing interests.

\section{Author details}

${ }^{1}$ Unidad de Bioquímica y Biología Molecular de Plantas, Centro de Investigación Científica de Yucatán, Mérida, Yucatán, Mexico. ${ }^{2}$ Departamento de Biología Molecular, Universidad Nacional de Río Cuarto, Río Cuarto, Córdoba, Argentina. ${ }^{3}$ CONA CYT- Centro de Investigación y Desarrollo en Agrobiotecnología Alimentaria (Consortium between Centro de Investigación y Desarrollo, A.C. and Centro de Investigación y Asistencia en Tecnología y Diseño del Estado de Jalisco), San Agustín Tlaxiaca, Hidalgo, Mexico. ${ }^{4}$ Centro de Investigación y Asistencia en Tecnología y Diseño del Estado de Jalisco (CIATEJ), Subsede Sureste, Yucatán, Mexico.

Received: 21 April 2020 Accepted: 7 January 2021

Published online: 25 January 2021

\section{References}

1. Damm U, Cannon PF, Woundenberg JH, Crous PW. The Colletotrichum acutatum species complex. Studies in Mycol. 2012;73(1):37-113. https://doi. org/10.3114/sim0010. 
2. Nam MH, Park MS, Lee HD, Yu SH. Taxonomic re-evaluation of Colletotrichum gloeosporioides isolated from strawberry in Korea. Plant Patho J. 2013;29(3):317-22. https://doi.org/10.5423/PPJ.NT.12.2012.0188.

3. Aiello D, Carrieri R, Guarnaccia V, Vitale A, Lahoz E, Polizzi G. Characterization and Pathogenicity of Colletotrichum gloeosporioides and C. karstii Causing Preharvest Disease on Citrus sinensis in Italy. J Phytopathol. 2015;163(3):168177. doi.org/https://doi.org/10.1111/jph.12299

4. Guarnaccia V, Aiello D, Cirvilleri G, Polizzi G, Susca A, Epifani F, Perrone G Characterisation of fungal pathogens associated with stem-end rot of avocado fruit in Italy. III International Symposium on Postharvest Pathology: Using Science to Increase Food Availability. Acta Hort. 2016;1144:133-9. https://doi.org/10.17660/ActaHortic.2016.1144.19.

5. Liu F, Tang G, Zheng X, Li Y, Sun X, Qi X, Zhou Y, Xu J, Chen H, Chang X, Zhang $S$, Gong G. Molecular and phenotypic characterization of Colletotrichum species associated with anthracnose disease in peppers from Sichuan Province. China Scientific Rep. 2016;6:32761. https://doi.org/10. 1038/srep32761.

6. de Silva DD, Ades PK, Crous PW, Taylor PWJ. Colletotrichum species associated with chili anthracnose In Australia Plant Pathology 2017;66:254267 doi: https://doi.org/10.1111/ppa.12572.

7. de Silva DD, Groenewald JZ, Crous PW, Ades PK, Nasruddin A, Mongkolporn O, Taylor PWJ. Identification, prevalence and pathogenicity of Colletotrichum species causing anthracnose of Capsicum annuum in Asia. IMA Fungus. 2019;10:8. https://doi.org/10.1186/s43008-019-0001-y.

8. Jayapala N, Mallikarjunaiah $\mathrm{NH}$, Puttaswamy $\mathrm{H}$, Gavirangappa $\mathrm{H}$, Ramachandrappa NS. Acibenzolar-S-methyl and $\beta$-amino butyric acidinduced upregulation of biochemical defense against Colletotrichum capsici infection in chilli (Capsicum annuum). Arch Phytopathol Plant Protection. 2020;53:3-4, 141-161. https://doi.org/10.1080/03235408.2020.1735138.

9. Ranathunge NP, Mongkolporn O, Ford R, Taylor PWJ. Colletotrichum truncatum Pathosystem on Capsicum spp: infection, colonization and defence mechanisms. Australasian Plant Pathol. 2012;41:463-73. https://doi. org/10.1007/s13313-012-0156-0.

10. Kazan K, Lyons R. Intervention of Phytohormone pathways by pathogen effectors. Plant Cell. 2014;26(6):2285-309. https://doi.org/10.1105/tpc.114 125419.

11. Janda M, Ruelland E. Magical mystery tour: salicylic acid signalling. Environ Exp Bot. 2015;114:117-28. https://doi.org/10.1016/j.envexpbot.2014.003.

12. Kalachova T, Puga-Freitas R, Kravets V, Soubigou-Repellin L, Balzergue S, Zachowski A, Ruelland E. The inhibition of basal phosphoinositidedependent phospholipase $\mathrm{C}$ activity in Arabidopsis suspension cells by abscisic or salicylic acid acts as a signalling hub accounting for an important overlap in transcriptome remodelling induced by these hormones. Environ Exp Bot. 2016;123:37-49. https://doi.org/10.1016/j. envexbot.2015.11.003.

13. Cacas J-L, Gerbeau-Pissot P, Fromentin J, Cantrel C, Thomas D, Jeannette E, Kalachova T, Mongrand S, Simon-Plas F, Ruelland E. Diacylglycerol kinases activate tobacco NADPH oxidase-dependent oxidative burst in response to cryptogein. Plant Cell Environ. 2017:40:585-98. https://doi.org/10.1111/pce.12771.

14. D’Ambrosio JM, Couto D, Fabro G, Scuffi D, Lamattina L, Munnik T, Andersson MX, Álvarez ME, Zipfel C, Ana M. Laxalta AM. Phospholipase C2 affects MAMP-triggered immunity by modulating ROS production. Plant Physiol 2017;175:970-981. doi: https://doi.org/10.1104/pp.17.00173.

15. Kalachova T, Janda M, Šašek V, Ortmannová J. Nováková petre Dobrev IP, Kravets V, Guivarc'h a, Moura D, Burketová L, Valentová O, Ruelland E. identification of salicylic acid-independent responses in an Arabidopsis phosphatidylinositol 4-kinase beta double mutant. Ann Bot. 2020;125:77484. https://doi.org/10.1093/aob/mcz112.

16. Munnik T, Testerink C. Plant phospholipid signaling: "in a nutshell". J Lipid Res. 2009;50:S260-5. https://doi.org/10.1194/jlr.R800098-JLR200.

17. Nakano M, Yoshioka H, Ohnishi K, Hikichi Y, Kiba A. Cell death-inducing stresses are required for defense activation in DS1-phosphatidic acid phosphatase-silenced Nicotiana benthamiana. J Plant Physiol. 2015;184:15-9. https://doi.org/10.1016/j.jplph.2015.06.007.

18. Testerink C, Munnik T. Molecular, cellular, and physiological responses to phosphatidic acid formation in plants. J Exp Bot. 2011;62(7):2349-61.

19. Hou QC, Ufer GD, Bartels D. Lipid signalling in plant responses to abiotic stress. Plant Cell Environ. 2016;39(5):1029-48. https://doi.org/10.1111/pce. 12666.

20. Altuzar-Molina AR, Muñoz-Sanchez JA, Vázquez-Flota FA, Monforte-González M, Racagni-Di Palma G, Hernández-Sotomayor SMT. Phospholipidic signaling and vanillin production in response to salicylic acid and methyl jasmonate in Capsicum chinense J. cells. Plant Physiol Biochem. 2011;49(2): 151-8. https://doi.org/10.1016/j.plaphy.2010.11.005.

21. Nakano M, Nishihara M, Yoshioka H, Takahashi H, Sawasaki T, Ohnishi K, Hikichi Y, Kiba A. Suppression of DS1 phosphatidic acid phosphatase confirms resistance to Ralstonia solanacearum in Nicotiana benthamiana. PLoS One. 2013;8(9):e75124.

22. van der Luit AH, Piatti T, van Doorn A, Musgrave A, Felix G, Boller T, Munnik T. Elicitation of suspension-cultured tomato cells triggers the formation of phosphatidic acid and diacylglycerol pyrophosphate. Plant Physiol. 2000; 123(4):1507-15.

23. Yamaguchi T, Minami E, Ueki J, Shibuya N. Elicitor-induced activation of phospholipases plays an important role for the induction of defense responses in suspension-cultured rice cells. Plant Cell Physiol. 2005;46(4):579-87.

24. Kaushal M, Mahuku G, Swennen R. Metagenomic insights of the root colonizing microbiome associated with symptomatic and non-symptomatic bananas in Fusarium wilt infected fields. Plants. 2020;9(2):263.

25. Zhou Y, Coventry DR, Gupta W, Fuentes D, Merchant A, Kaiser BN, Li J, Wei Y, Liu H, Wang Y, Gan S, Denton MD. The preceding root system drives the composition and function of the rhizosphere microbiome. Genome Biol. 2020;21:1-19.

26. Robin GP, Kleemann J, Neumann U, Cabre L, Dallery J-F, Lapalu N, O'Connel RJ. Subcellular localization screening of Colletotrichum higginsianum effector candidates identifies fungal proteins targeted to plant peroxisomes, golgi bodies and microtubules. Front Plant Sci. 2018;9:562. https://doi.org/ 10.3389/fpls.2018.00562.

27. Fang Y-L, Xia L-M, Wang P, Zhu L-H, Ye J-R, Huang L. The MAPKKK CgMck1 is required for cell wall integrity, Appressorium development, and pathogenicity in Colletotrichum gloeosporioides. Genes. 2018;9(11):543. https://doi.org/10.3390/genes9110543.

28. Mogg C, Bonner C, Wang L, Schernthaner J, Smith M, Desveaux D, Subramaniam R. Genomic identification of the TOR signaling pathway as a target of the plant alkaloid antofine in the phytopathogen Fusarium graminearum. Am Soc Microbiology. 2019;10(3):e00792-19. https://doi.org/ 10.1128/mBio.00792-19.

29. Teixeira PJL, Colaianni N, Fitzpatrick CR, Dangl JL. Beyond pathogens: microbiota interactions with the plant immune system. Curr Opin Microbiol. 2019;49:7-17. https://doi.org/10.1016/j.mib.2019.08.003.

30. Lamichhane JR, Durr C, Schwanck AA, Robin M-H, Sarthou J-P, Cellier V, Messean A, Aubertot J-N. Integrated management of damping-off diseases. A review Agronomy for Sustainable Develop 2017;37(2):25. doi: https://doi. org/10.1007/s13593-017-0417-y.

31. Murashige T, Skoog F. A revised medium for rapid growth and bio assays with tobacco tissue cultures. Physiol Plant. 1962;15(3):473-97. https://doi. org/10.1111/j.1399-3054.1962.tb08052.x.

32. Dhingra OD, Burton J. Basic plant pathology methods. Cleveland, Ohio: CRC press; 1995.

33. Ko W. Chemical stimulation of sexual reproduction in Phytophthora an Pythium. Bot Bull Acad Sin. 1998;39:81-6.

34. Gou LY, Ko WH. Two widely accesible media for growth and reproduction of phytophthora and pythium. Appl Environ Microbiol. 1993;59(7):2323-2325. doi: 0099-2240/93/072323-03\$02.00/0.

35. Sharma M, Ghosh R, Tarafdar A, Telangre R. An efficient method for zoospore production, infection and real-time quantification of Phytophthora cajani causing Phytophthora blight disease in pigeonpea under elevated atmospheric CO2. BMC Plant Biol. 2015;15:90. https://doi.org/10.1186/s12870-015-0470-0.

36. Shipton WA. Zoospore induction and release in a Pythium causing equine Phycomycosis. Trans Br Mycol Soc. 1985;84(Jan):147-55. https://doi.org/10. 1016/S0007-1536(85)80228-X

37. Kamoun S, Young M, Glascock CB, Tyler BM. Extracellular protein elicitors from Phytophthora - host-specificity and induction of resistance to bacterial and fungal Phytopathogens. Mol Plant-Microbe Interactions. 1993;6(1):1525. https://doi.org/10.1094/MPMI-6-015.

38. Meyer F, Paarmann D, D'Souza M, Olson R, Glass EM, Kubal M, Paczian T, Rodríguez A, Stevens R, Wilke A, Wilkening J, Edwards RA. The metagenomics RAST server-a public resource for the automatic phylogenetic and functional analysis of metagenomes. BMC Bioinformatics. 2008:9(1):386. https://doi.org/10.1186/1471-2105-9-386.

39. Altschul S, Gish W, Miller W, Myers E, Lipman D. Basic local alignment search tool. J Mol Biol. 1990:215(3):403-10. https://doi.org/10.1016/S00222836(05)80360-2. 
40. Encyclopedia of Life (http://www.eol.org/). Accessed 10 March 2017.

41. Global Catalog of Microorganisms (http://gcm.wfcc.info). Accessed 22 June 2017.

42. Integrated Taxonomic Information System (https://www.itis.gov/). Accessed 24 May 2017.

43. Livemap (http://lifemap-ncbi.univ-lyon1.fr/). Accessed 6 June 2017.

44. Moral J, Bouhmidi K, Trapero A. Influence of fruit maturity, cultivar susceptibility, and inoculation method on infection of olive fruit by Colletotrichum acutatum. Plant Dis. 2008;92(10):1421-6. https://doi.org/10. 1094/PDIS-92-10-1421.

45. Berridge MV, Tan AS. Characterization of the cellular reduction of 3-4,5dimethylthiazol-2-yl)-2,5-diphenyltetrazolium bromide (MTT): subcellular localization substrate dependence, and involvement of mitochondrial electron transport on MTT reduction. Arch Biochem Biophys 1993;303(2): 474-482. doi: https://doi.org/10.1006/abbi.1993.1311.

46. Racagni G, Villasuso AL, Pasquare SJ, Giusto NM, Machado E. Diacylglycerol pyrophosphate inhibits the alpha-amylase secretion stimulated by gibberellic acid in barley aleurone. Physiol Plant. 2008;134:381-93. https:// doi.org/10.1111/j.1399-3054.2008.01148.x.

47. Smith PK, Kronhn RI, Hermanson GT, Mallia AK, Gartner FH, Provenzano MD, Fujimoto EK, Goeke NM, Olson BJ, Klenk DC. Measurement of protein using Bicinchoninic acid. Anal Biochem. 1985;150(1):76-85.

48. Racagni-Di Palma G, Brito-Argaez L, Hernandez-Sotomayor SMT. Phosphorylation of signaling phospholipids in Coffea arabica cells. Plant Physiol Biochem. 2002;40(11):899-906. https://doi.org/10.1016/S09819428(02)01450-X.

49. SOL Genomics Network database (https://www.sgn.cornell.edu/). Accessed 18 August 2017

50. Thompson JD, Gibson TJ, Plewniak F, Jeanmougin F, Higgins DG. The ClustalX windows interface: flexible strategies for multiple sequence alignment aided by quality analysis tools. Nucleic Acids Res. 1997;25:4876-82.

51. Tamura K, Stecher G, Peterson D, Filipski A, Kumar S. MEGA6: molecular evolutionary genetics analysis version 6.0. Mol Biol Evol. 2013;30(12):2725-9. https://doi.org/10.1093/molbev/mst197.

52. Rao X, Huang X, Zhou Z, Lin X. An improvement of the 2'(-delta delta CT) method for quantitative real-time polymerase chain reaction data analysis. Biostat Bioinf Biomath. 2013;3(3):71-85.

53. Sharma G, Shenoy BD. Colletotrichum fructicola and C. siamense are involved in chilli anthracnose in India. Archives of Phytopathology and Plant Protection. Taylor \& Francis, 47(10), 2014. p. 1179-1194. doi: https://doi.org/ 10.1080/03235408.2013.833749.

54. Kim K-H, Yoon J-B, Park H-G, Park EW, Kim YH. Structural modifications and programmed cell death of chili pepper related to resistance responses to Colletotrichum gloeosporioides infection. Phytopahol: Genetics and Resist. 2004:94(12):1295-304. https://doi.org/10.1094/PHYTO.2004.94.12.1295.

55. Naton B, Hahlbrock K, Schmelzer E. Correlation of rapid cell death with metabolic changes in fungus-infected, cultured parsley cells. Plant Physiol. 1996;112:433-44. https://doi.org/10.1104/pp.112.1.433.

56. Sutherland MW. The generation of oxygen radicals during host plant responses to infection. Physiol Mol Plant Pathol. 1991;39:79-93.

57. Tzeng DD, De Vay JE. Role of oxygen radicals in plant disease development. In: Andrews JH, Tomerup IC, editors. Advances in plant pathology, vol. 10. London: Academic Press; 1993. p. 1-33.

58. Kulkarni AP, Mitra A, Chaudhuri J, Byczkowski JZ, Richards I. Hydrogen peroxide: a potent activator of dioxygenase activity of soybean lipoxygenase. Biochem Biophys Res Commun. 1990;166:417-23. https://doi. org/10.1016/0006-291x(90)91961-Q.

59. Munnik T, Meijer HJ, Ter Riet B, Hirt H, Frank W, Bartels D, Musgrave A. Hyperosmotic stress stimulates phospholipase D activity and elevates the levels of phosphatidic acid and diacylglycerol pyrophosphate. Plant J. 2000;22(2):147-54. https://doi.org/10.1046/j.1365-313x.2000.00725.x.

60. Zalejski C, Zhang Z, Quettier A-L, Maldiney R, Bonnet M, Brault M, Demandre C, Miginiac E, Rona J-P. Sotta B, Jeanette E. Diacylglycerol pyrophosphate is a second messenger of abscisic acid signaling in Arabidopsis thaliana suspension cells. Plant J 2005;42(2):145-152. doi:https://doi.org/10.1111/j.1365-313X.2005.02373.x.

61. Testerink C, Munnik T. Plant response to stress: Phosphatidic acid as a second messenger. Encyclopedia Plant Crop Sci. 2004:995-8. https://doi.org/ 10.1081/E-EPCS120010659.

62. Ruelland E, Valentova O. Editorial: lipid signaling in plant development and responses to environmental stresses. Front Plant Sci. 2016:7(324):1-3. https://doi.org/10.3389/fpls.2016.00324.
63. Meijer HJG, Arisz SA, Van Himbergen JAJ, Musgrave A, Munnik T. Hyperosmotic stress rapidly generates lyso-phosphatidic acid in Chlamydomonas. Plant J. 2001;25(5):541-8. https://doi.org/10.1046/j.1365313x.2001.00990.x

64. den Hartog M, Verhoef N, Munnik T. Nod factor and elicitors activate different phospholipid signaling pathways in suspension-cultured alfalfa cells. Plant Physiol. 2003;132(1):311-317. doi: doi.org/https://doi.org/10.1104/ pp.102.017954.

65. Darwish E, Testerink C, Khalil M, El-Shihy O, Munnik T. Phospholipid signaling responses in salt-stressed rice leaves. Plant Cell Physiol. 2009;50(5): 986-97. https://doi.org/10.1093/pcp/pcp051.

66. Zonia L, Munnik T. Cracking the Green Paradigm: Functional Coding of Phosphoinositide Signals in Plant Stress Responses. From: Biology of Inositol $s$ and Phosphoinositides. Lahiri A and Biswas B (eds). Netherlands: Springer; 2006. p. 207-238

67. de Jong CF, Laxalt AM, Bargmann BO, de Wit PJ, Joosten MH, Munnik T. Phosphatidic acid accumulation is an early response in the Cf-4/Avr4 interaction. Plant J. 2004;39(1):1-12. https://doi.org/10.1111/j.1365-313X.2004 02110.x.

68. Bargmann BO, Munnik T. The role of phospholipase D in plant stress responses. Curr Opin Plant Biol. 2006;9(5):515-22. https://doi.org/10.1016/j. pbi.2006.07.011.

69. Andersson MX, Kourtchenko O, Dangl JL, Mackey D, Ellerström M. Phospholipase-dependent signalling during the AvrRpm1- and AvrRpt2induced disease resistance responses in Arabidopsis thaliana. Plant J. 2006; 47(6):947-59. https://doi.org/10.1111/j.1365-313X.2006.02844.x.

70. Gonorazky G, Guzzo MC, Abd-El-Haliem AM, MHAJ J, Laxalt AM. Silencing of the tomato phosphatidylinositol-phospholipase C2 (SIPLC2) reduces plant susceptibility to Botrytis cinerea. Molecular Plant Pathol. 2016;17:1354-63. https://doi.org/10.1111/mpp.12365.

71. Goto K, Hozumi Y, Kondo H. Diacylglycerol, phosphatidic acid, and the converting enzyme, diacylglycerol kinase, in the nucleus. Biochim Biophys Acta. 2006;1761(5-6):535-41. https://doi.org/10.1016/j.bbalip.2006.04.001

72. Van den Bout I, Divecha N. PIP5K-driven Ptdlns $(4,5) P_{2}$ synthesis: regulation and cellular functions. J Cell Sci. 2009;122:3837-50. https://doi.org/10.1242/ jcs.056127.

73. Dong W, Lv H, Xia G, Wang M. Does diacylglycerol serve as a signaling molecular in plants. Plant Signal Behav. 2012;7(4):472-5. https://doi.org/10. 4161/psb.19644

74. Zhang WD, Chen J, Zhang H, Song F. Overexpression of a rice diacylglycerol kinase gene OsBIDK1 enhances disease resistance in transgenic tobacco. Mol Cell. 2008;26(3):258-64.

\section{Publisher's Note}

Springer Nature remains neutral with regard to jurisdictional claims in published maps and institutional affiliations.

Ready to submit your research? Choose BMC and benefit from

- fast, convenient online submission

- thorough peer review by experienced researchers in your field

- rapid publication on acceptance

- support for research data, including large and complex data types

- gold Open Access which fosters wider collaboration and increased citations

- maximum visibility for your research: over $100 \mathrm{M}$ website views per year

At $\mathrm{BMC}$, research is always in progress.

Learn more biomedcentral.com/submission 